\title{
The effect of Supply Chain Practices on Business Performance in PT.Putra Tunggal Perkasa
}

\author{
Devi Rahnjen Wijayadne1) \\ devirahnjen@gmail.com \\ Timotius Fcw Sutrisno2) \\ timotius.febry@ciputra.ac.id \\ Aria Ganna Henryanto ${ }^{3)}$ \\ aria.ganna@ciputra.ac.id \\ Bontor Dodi Pasaribu ${ }^{4)}$ \\ bontor.pasaribu@ciputra.ac.id \\ 1) 2) 3)4)Ciputra University Surabaya
}

\begin{abstract}
Supply chain management has evolved into value chain management driven by consumer needs. Besides pursuing increased efficiency, it recognizes the importance of consumer needs and attempts to capture the intricacies of consumer value as a source of differentiation and competitiveness in the supply chain. The purpose of this study is to look at the effect of supply chain practices on PT. Mighty only son. This study uses a quantitative method with 30 respondents consisting of all non-driver staff. Based on the results of research on customer relationship variables, information quality, information technology can be concluded that these variables have an impact on business performance partially.
\end{abstract}

Keywords: Supply chain management, supply chain practices, logistics, business performance 


\section{PRELIMINARY}

Supply chain management is an integration of company components and its partners, like warehouses, suppliers, distributors, factories, and various other business units to create an effective distribution dynamic as an efficient measure of production costs and customer satisfaction (Manders, Caniëls, \& Ghijsen, 2014). The concept of supply chain management is a new concept that sees all company activities as an integrated part in the sense that company integration is in the upstream in providing raw materials and integration in the downstream as a distribution and product marketing process. Supply chain management practice is an effort to increase the effectiveness of the performance and the competitive capabilities of a business. Performance here is a result obtained from a production process in the form of goods and services as an effort to reduce production costs and stakeholder satisfaction (USAID Deliver, 2011).

Innovation is defined as the process of equipping an organization with new capabilities, increasing or increasing utility within the company (Roehrich, 2004). Supply chain management innovation often involves collaborative relationships and partners, especially in terms of leveraging innovations that are triggered by industrial competition with one another and considered mutually beneficial, such as new technologies and information systems. Developing supply chain competitiveness through the use of innovation often involves pooling capabilities and resources power and reconfiguration to adjust and coordinate supply chain offerings in a new and more satisfying way for customers, thereby creating flexibility and efficiency in supply chain operations (Nouri Bagher, 2018).

Company performance is what the company produces within a certain period at a predetermined standard. Business performance refers to how much the company is oriented towards the market and profit goals (Stevenson \& Spring, 2009).

PT Putra Tunggal Perkasa is a company engaged in logistics services, supplying construction materials in the form of cast stone and providing dump truck services. This company has been operating since 2008 and currently has 4 branches in 4 cities, namely: Gresik, Surabaya, Pasuruan and Lamongan. Each branch has several projects that are being carried out, including:

Table 1.1 Total Project PT.Putra Tunggal Perkasa 2019-2020

\begin{tabular}{lccc}
\hline Subsidiaries & Big Project & Middle Project & Micro Project \\
\hline Gresik & 1 & 1 & 0 \\
Surabaya & 2 & 2 & 1 \\
Pasuruan & 0 & 1 & 3 \\
Lamongan & 0 & 1 & 3 \\
Total Project & 3 & 5 & 7 \\
\hline
\end{tabular}

source: Internal source company 2019-2020

Based on table 1.1 shows some information, at the Gresik Branch there is 1 large project and 1 handling project. In the Surabaya branch there are 2 large projects, 2 medium projects and 1 small project. In the Pasuruan branch there are 1 medium project and 3 small projects. In the Lamongan branch, there are 1 medium project and 3 small projects. With a total of 13 projects in 2019/2020. This shows that there are quite a lot of projects undertaken by PT. Putra Tunggal Perkasa. This achievement is inseparable from the existing and created supply chain performance in the company.

Table 1.2 Total Project PT.Putra Tunggal Perkasa 2015-2019 
PRIMANOMICS : JURNAL EKONOMI DAN BISNIS - VOL. 19. NO. 1 (2021)

Versi Online Tersedia di : https://jurnal.ubd.ac.id/index.php/ds

| 1412-632X (Cetak) | 2614-6789 (Online) |

\begin{tabular}{cccc}
\hline Year & Total Project & Closing & $\begin{array}{c}\text { Project } \\
\text { Achievements }\end{array}$ \\
\hline 2015 & 12 & 11 & $92 \%$ \\
2016 & 9 & 9 & $100 \%$ \\
2017 & 11 & 11 & $100 \%$ \\
2018 & 14 & 13 & $93 \%$ \\
2019 & 13 & 11 & $85 \%$ \\
\hline
\end{tabular}

source: Internal source company 2019-2020

Based on Table 1.2, it can be seen there has been an increase and decrease in the number of projects have been done by PT Putra Tunggal Perkasa. In 2015 there were 12 projects, in 2016 there were 9 projects, in 2017 there were 11 projects, in 2018 there were 14 projects and in 2019 there were 13 projects. When viewed in the project achievements column, there is a decrease in performance in each working year with the lowest percentage in 2019 , namely $85 \%$. This is a phenomenon in itself for researchers, where the data states that there has been a disruption in the operational implementation of a number of projects entrusted to PT Putra Tunggal Perkasa by consumers. this is the basis for this further research to be carried out. The obstacles that occur are as follows:

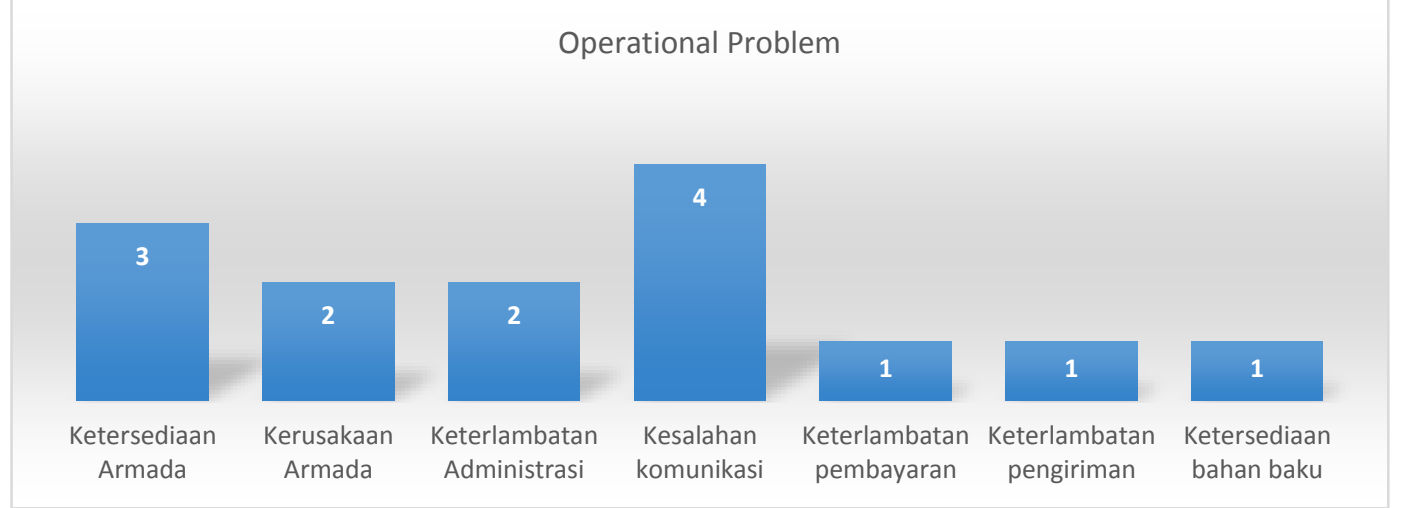

Picture 1.3. Operational Problem PT Putra Tunggal Perkasa

One of the operational constraints comes from the availability of a fleet that is unable to meet project needs. In the logistics and transportation industry, the fleet is a very important company asset in creating value in business processes so that the availability of the fleet can reflect the quality of company services (George \& Xia, 2011). The unavailability of the fleet (ketersediaan armada) caused PT. Putra Tunggal Perkasa is not able to meet the demand for customer projects so that the company's performance is not optimal. George and Xia (2011) found that fleet unavailability is closely related to fleet-sizing or fleet procurement and relative fleet utilization. Decision making to determine the optimal fleet number requires accurate and up-to-date information regarding fleet utilization (George and Xia, 2011). At PT Putra Tunggal Perkasa, there are also operational constraints in the form of communication errors where it can cause the information shared between partners in the supply chain to be inaccurate and up to date, causing the determination of the number of fleets to be not optimal and leading to fleet unavailability in meeting project needs.

PT Putra Tunggal Perkasa uses a single loop supply chain. which means that the material is only taken from one level of supplier and sent to one level of material user. The flow is as follows: 


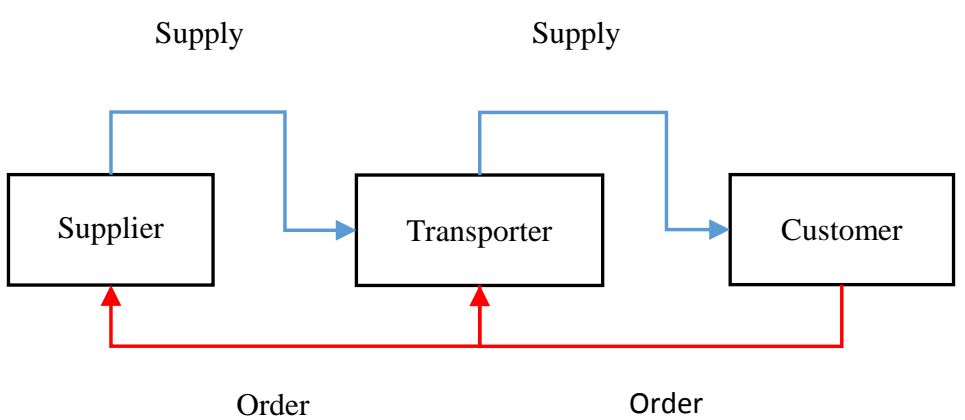

Gambar 1.2. Model Supply Chain Single Loop PT. Putra tunggal perkasa

In the material and logistics industry, the phenomenon of supply chain management is different from the manufacturing industry. Where the logistics industry supply chain is more concise by not going through distribution channels. Consumers can directly order transportation needs or construction material services to PT. Putra Tunggal Perkasa. Then, PT. Putra Tunggal Perkasacan meet the needs of consumers directly. To meet consumer needs, PT. Putra Tunggal Perkasa needs a fleet supply and raw materials that can be ordered directly from suppliers without going through distributors. However, the implementation of effective supply chain practices can still affect company performance.

Understanding and implementing supply chain management practices plays an important role for organizations to remain competitive and to increase profitability in increasingly competitive global markets (Herden, 2017). There are quite a number of supply chain practices that can be used, such as supplier relationships, customer relationships, information sharing (IS), information and communication technology for lean manufacturing, agile manufacturing, outsourcing, postponement, Green SCM and reverse logistics (Gorane \& Kant, 2017). operational constraints of PT. Putra Tunggal Perkasa, the unoptimal supply chain practices need to be improved and related with customer relationships to closes project needs with fleet availability, Information Quality regarding accuracy and current information, information technology related to information technology systems that support information sharing. Sukati et al. (2020) found that customer relationships, information quality sharing, information technology have a significant positive effect on organizational performance. Based on the background and literature review, the researcher is interested in conducting a study entitled "The Influence of Supply chain practices on Business Performance of PT. Putra Tunggal Perkasa".

\section{Literature review and Hypothesis Development}

Supply chain is a unit consisting of all the stages involved, either directly or indirectly, to fulfill customer demand. Supply chain includes not only producers and distributors, but also transporters, inventory, retailers, and end consumers themselves (Manders et al., 2014). Others define the supply chain as the integration of the core business processes of the end consumer through the initial supplier as a provider of products, services and information that add value to consumers and other stakeholders. Simply put, supply chain is the flow of both products and information as well as 
processes for the delivery of products and services from sources (suppliers) to destination locations (customers or buyers) (Herden, 2017).

In development of supply chain management is described as an entity consisting of several related companies and forging a cooperative cooperation in order to achieve a synergy in the distribution of goods, information, and cash flow. Companies that managing supply chain realize company's internal excellence is not enough to achieve its strategic goals, it also requires external excellence in the supply chain to achieve the company's strategic and competitive goals (Tortorella, Giglio, Limon-Romero, Tortorella, \& Limon-Romero, 2018). This is explained the basis of the supply chain management philosophy where all efforts made by a company to collaborate or collaborate with other companies are part of supply chain management activities.

Open management in the supply chain is defined as "systemic and strategic coordination activities of traditional internal business functions of the company and throughout the company in the supply chain, for the purpose of improving the long-term performance of the company individually and supply chain performance as a whole (Herden, 2017).

\section{Supply Chain Integration}

Philosophically, supply chain management uses a systematic approach to view the supply chain as an integrated unit, not as a collection of fragments that operate independently (Herden, 2017). There are several supply chain integrations, namely:

Internal integration, within a company can replace the role of structural and administrative supply chain capabilities that have an interactive relationship with cost leadership capabilities for performance improvement.

External Integration, in relation to suppliers and customers, this integration can replace the role of technology and logistics supply chain capabilities that interact with innovative marketing, differentiation, and customer service capabilities for performance improvement.

\section{Customer Relationship}

All supply chain management practices implemented by an organization function to increase customer satisfaction, build long-term relationships and handle customer complaints efficiently under the customer relationship. Customer expectations are very dynamic in nature and organizations need to assess them regularly and perform operational functions accordingly. The existence of a good customer relationship affects the level of customer satisfaction and the company's business performance (Kumar \& Kushwaha, 2015). Effective customer relationships are also able to help companies gain customer loyalty where customers will be willing to reuse and recommend the products offered and pay for products at premium prices, so that the company's sales and market share will increase (Banerjee and Mishra, 2015). A healthy customer relationship can encourage customers to provide input to the company regarding the desired product, this input can help the company respond to customer needs and recent market changes so that the company can produce products that are able to provide customer satisfaction (Gorane \& Kant, 2017) 


\section{Information Quality}

Information quality is a multidimensional phenomenon that is discussed by various parties to identify and classify measures of the quality of information that exist within an organization. Information is very important for evaluating supply chain performance and plays an important role in the supply chain (Khan, Chaabane, \& Dweiri, 2019). In addition, a good information network system can improve communication collaboration between parts of the organization and facilitate knowledge exchange for mutual growth (Dyer , 1991). if information is shared in an effective and controlled manner which results in an integrated form and a coordinated supply chain, information can be a source of competitive advantage and improve business performance (Banerjee \& Mishra, 2017). Accurate and up-to-date information can reduce the bullwhip effect where companies can forecast optimal production requirements so as to reduce inventory and operational costs (Kumar, Sahu, Shamna, \& Ranjan, 2018) (Kumar et al., 2019). This is supported by the theory of constraints developed by Goldratt (1990) where the supply chain system experiencing capacity constraints or limited production capacity causes members in the supply chain to invest excessively in these supplies thus increasing inventory costs. This excessive investment is caused by asymmetric information among members of the supply chain where retailers know market information and suppliers know production capacity information, but supply chain members keep this information confidential (Shen et al., 2019). Quality information sharing can reduce asymmetric information and help each member of the supply chain determine the optimal buffer constraint according to demand conditions and product availability (Simatupang et al., 2004). In addition, quality information sharing can help each partner in the supply chain to better understand the needs of their end customers and respond more quickly to market changes so as to gain customer loyalty and increase company sales (Sukati et al., 2020).

Not all information shared can improve the company's business performance, only quality information can improve organizational performance (Banerjee and Mishra, 2015). Quality information is accurate, current, complete and useful information to solve partner problems in the supply chain (Banerjee and Mishra, 2015).

\section{Information Technology}

Gaining recognition in digital era at a broader level becom an important factor to consider in business development and improving supply chain performance in companies. Hardware and software innovation in information technology plays an important role in contributing to improving business performance. Using communication media for transportation service providers is a vital tool in the exchange and receipt of information. Information Technology serves as a low-cost alternative to previous communication methods with the availability of accurate information ( $\mathrm{Li}$, Cui, Huo, \& Zhao, 2019). Information technology also plays a key role in reducing the cost of internal and external coordination (Kim and Mahoney, 2006) and facilitate the development and exchange of strategically relevant information and knowledge among supply chain partners (Dyer and Singh, 1998; Fulk and Boyd, 1991). The ease and speed of sharing quality information facilitated by information technology can help each partner in the supply chain to make appropriate, fast and flexible strategic decisions in facing market conditions to meet customer needs (Sukati et al., 2020; Yunis et al. 2018). Information technology in B2B (business to business) transactions can open important 
data related to prices and production costs which can lead to more transparent information between partners in the supply chain so that it can make it easier for buyers to find out information related to incentives to be obtained and encourage these buyers to join B2B transactions. In the end, Information technology can increase the incentives of each partner to an increase in sales and their market share (Theofilus et al., 2020; Zhou et al., 2018). Using information technology can also facilitate corporate innovation that supports the continuous improvement of product quality offered by the company by adjusting to changing market needs so that the company can meet customer needs and increase competitive advantage (Yunis et al., 2018; Sutrisno and Adryan, 2020).

\section{Business Performance}

Measuring business performance is important for every company. The performance measurement function is to help track performance levels and allows making decisions or strategies to be taken for the future. However, almost no single measure of performance can accurately measure business performance. The company is currently experiencing quite tough competition, where business performance is a measure of the company's position compared to competitors outside (Nouri Bagher, 2018). The company is currently experiencing quite fierce competition, where business performance is one measure of the company's position compared to competitors outside (Nouri Bagher, 2018).

\section{Relationship Between Variables and Hypotheses}

Supply chain practices are activities carried out by an organization to make the entire supply chain effective. The SCM field is a very popular field which can be seen from the contribution of various aspects. When viewed there are several supply chain practices that have an impact on business performance achievement (Kumar \& Kushwaha, 2015).

\section{Customer Relationship And Business Performance}

A company's customer relationship practices can affect its success in managing the basic supply chain and its performance. Customer relationship focuses on knowing about the perspective of organizational members on customers to produce products or services for customer satisfaction which in turn improves buyer-supplier relationships. They can understand the needs of the end consumer better and this enables them to be responsive to rapid market changes and bring responsiveness to improved business performance in the organization.

\section{Information Quality and Business Performance}

Information can be a source of competitive advantage if shared in a controlled manner which results in an integrated form and a coordinated supply chain. Several studies have stated that there is a relationship between information quality and business performance (Hasan, 2013; Khan et al., 2019). They provide evidence that the quality of information has a positive impact on sustainable business performance.

\section{Information Technology and Business Performance}

Information Technology serves as a low-cost alternative to previous communication with the availability of accurate information. The purpose of Information 
Technology is to increase customer satisfaction. Customer satisfaction can be fulfilled through timely delivery with accuracy, product availability, responsiveness and flexibility from service providers.

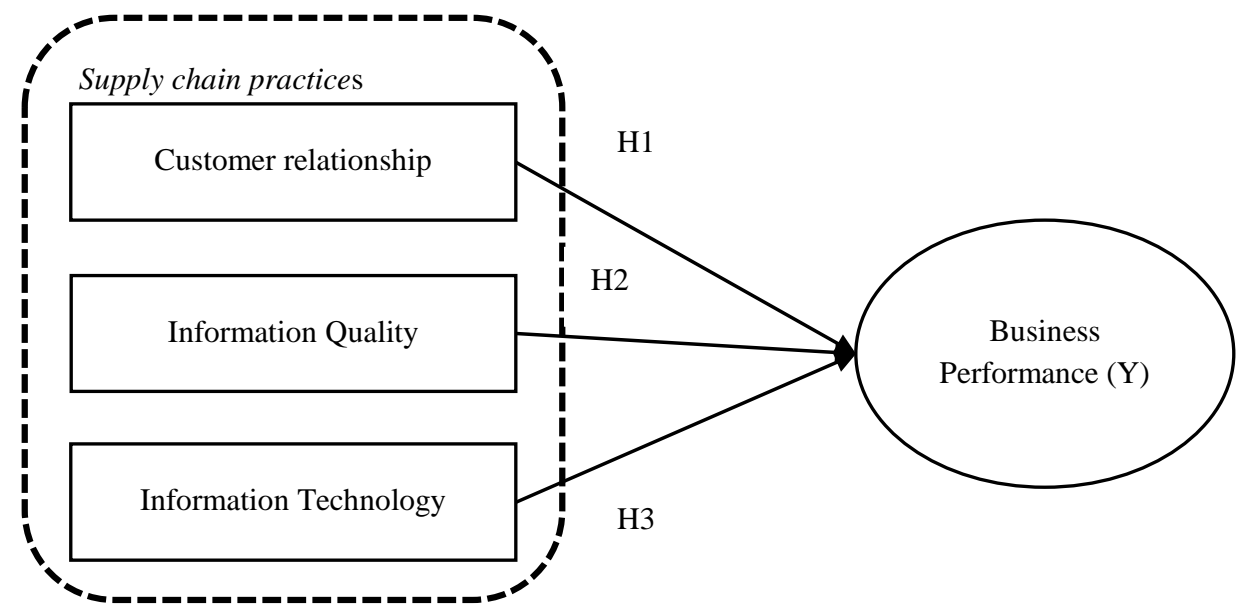

Picture 2.1 Analysis Model

\section{RESEARCH METHOD}

This research uses quantitative research methods by collecting and analyzing data using statistics. According to Kurniawan and Puspitaningtyas (2016: 18) The quantitative research method is structured research and has data that can be generalized to the population studied. The sample method used in this study is the non-probability method, where not all population units have the opportunity to be research sample. Therefore, this study uses a sample of PT. Putra Tunggal Perkasa in East Java.

There are two types of data used in this study, first, Quantitative data, is the data obtained from the company in the form of computable data or numbers obtained from the PT. Putra Tunggal Perkasa in East Java. Second, Qualitative data, is the form of information is the result of initial interviews with PT. Putra Tunggal Perkasa in East Java. There are two resources used in this study, namely: Primary data, namely data obtained from direct information provided by the first source from direct observation and interviews with parties related to the research problem.

The data collection method used in this study is field research: the authors collect data by going directly to the field through observations in the company (observation). The method used is purposive random sampling method, which means that the selected sample has a number of certain criteria so that it can become a research sample.

The data in this study were obtained through distributing E-questionnaires in the form of a google form containing questions about the supply chain practices that consist of customer relationships, information quality and information technology on business performance. The primary data measurement scale uses the Likert scale, there are five indicators for the Likert scale answer, namely: Strongly Disagree (STS) has a score of 1, Disagree (TS) has a score of 2, Simply Agree (CS) has a score of 3, Agree (S) has a score of 4 and Strongly Agree (SS) has a score of 5. 


\section{Data analysis method}

In this study the data are presented as follows: Descriptive Analysis and Multiple Regression Analysis, namely an analysis to see the extent of the influence of supply chain practices variables consisting of customer relationships, information quality and information technology on business performance of PT. Putra Tunggal Perkasa in East Java. Multiple regression analysis uses the equation formula as quoted in Sugiyono (2005: 261) :

Information:

$$
Y=a+b 1 X 1+b 2 X 2+b 3 X 3+e
$$

$\mathrm{Y}=$ business performance, $\mathrm{a}=$ constant, $\mathrm{b} 1=$ regression coefficient of variable $\mathrm{X} 1, \mathrm{X} 1=$ customer relationship, $\mathrm{b} 2=$ regression coefficient of variable X2, X2 = Information Quality, B3 = regression coefficient of variable X3, X3 = Information Technology, e = Error

\section{RESULTS AND DISCUSSION}

\section{Data analysis}

Respondents used in this study were non-driver staff employees of PT. Putra Tunggal Perkasa as many as 30 staff. The selected staff has a minimum service period of 2 years and is directly related to the upstream or downstream supply chain, and based on the results of the questionnaire obtained, the following data are obtained:

Table 4.1: Gender of respondents

\begin{tabular}{cccc}
\hline & Gender & Frequency & Percent \\
\hline \multirow{3}{*}{ Valid } & Male & 26 & 86,7 \\
& Female & 4 & 13,3 \\
& Total & 30 & 100 \\
\hline
\end{tabular}

source: Internal source 2020

Tabel 4.2: Years of service

\begin{tabular}{|c|c|c|c|}
\hline \multicolumn{2}{|r|}{ Years of service } & Frequency & Percent \\
\hline \multirow{8}{*}{ Valid } & 2 & 3 & 10 \\
\hline & 3 & 4 & 13,3 \\
\hline & 4 & 2 & 6,7 \\
\hline & 5 & 6 & 20 \\
\hline & 6 & 8 & 26,7 \\
\hline & 7 & 2 & 6,7 \\
\hline & 8 & 5 & 16,7 \\
\hline & Total & 30 & 100 \\
\hline
\end{tabular}

source: Internal source 2020

Tabel 4.3: level of education

\begin{tabular}{llcc}
\hline & & Frequency & Percent \\
\hline \multirow{4}{*}{ Valid } & High school & 2 & 6,7 \\
& Diploma & 21 & 70 \\
& Bachelor & 7 & 23,3 \\
& Total & 30 & 100 \\
\hline
\end{tabular}

source: Internal source 2020 
Of the 30 questionnaires that were distributed, 30 were completely filled out. The respondents were divided into 2 genders, namely 26 men $(86.7 \%)$ and 4 women $(13.3 \%)$. The respondents were divided into several long duration of work, namely 3 people with a duration of 2 years (10\%), 4 people with a duration of 3 years $(13.3 \%)$, 2 people with a duration of 4 years $(6.7 \%), 3$ people with a duration of 2 years ( $10 \%), 6$ people with a duration of 5 years $(20 \%), 2$ people with a duration of 7 years $(6.7 \%), 5$ people with a duration of 8 years $(16.7 \%)$. The respondents were divided into 3 levels of education, namely: 2 people with high school education (6.7\%), 21 people with a Diploma education (70\%), 7 people with an undergraduate education (23.3\%).

\section{Analysis of Respondents' Answers}

The following is a description of the respondents' answers to each statement of the research variables.

Tabel 4.5 Respondents' answers

\begin{tabular}{lccc}
\hline \multicolumn{1}{c}{ Variabel } & Mean & Std. Deviasi & Category \\
\hline Customer relationship (X1) & & \\
X1.1 & 4,27 & 0,868 & Agree \\
X1.2 & 4,27 & 0,691 & Agree \\
X1.3 & 4,37 & 0,765 & Agree \\
Rata_rata & 4,30 & 0,77 & Agree \\
\hline Information quality $(\mathrm{X} 2)$ & & \\
X2.1 & 4,03 & 0,669 & Agree \\
X2.2 & 4,07 & 0,691 & Agree \\
Rata-rata & 4,05 & 0,68 & Agree \\
\hline Information Technology (X3) & & \\
X3.1 & 4,03 & 0,85 & Agree \\
X3.2 & 3,6 & 0,968 & Agree \\
X3.3 & 3,9 & 0,662 & Agree \\
Rata-rata & 3,84 & 0,83 & Agree \\
\hline Business Performance (Y) & & \\
Y1.1 & 4 & 0,743 & Agree \\
Y1.2 & 3,97 & 0,765 & Agree \\
Y1.3 & 4 & 0,695 & Agree \\
Rata-rata & 3,99 & 0,73 & Agree \\
\hline
\end{tabular}

source: Internal source 2020

\section{Validity test}

The validity test is a test of data instruments to find out how appropriate each item or question is in measuring a variable. Table 4.6 is the result of the validity test for each variable.

Tabel 4.6 Validitas and Reliability test

\begin{tabular}{cccc}
\hline Variabel & Nilai Sig (2tailed) & Cronbach Alpha & Kesimpulan \\
\hline X1.1 & Customer Relationship (X1) & & Valid dan Reliable \\
X1.2 & 0,000 & 0,688 & Valid dan Reliable \\
X1.3 & 0,000 & & Valid dan Reliable \\
\hline & 0,000 & 0,933 & Valid dan Reliable
\end{tabular}




\begin{tabular}{|c|c|c|c|}
\hline $\mathrm{X} 2.2$ & 0,000 & & Valid dan Reliable \\
\hline \multicolumn{3}{|c|}{ Information Technology (X3) } & \\
\hline X3.1 & 0,000 & \multirow{3}{*}{0,912} & Valid dan Reliable \\
\hline X3.2 & 0,000 & & Valid dan Reliable \\
\hline $\mathrm{X} 3.3$ & 0,000 & & Valid dan Reliable \\
\hline \multicolumn{3}{|c|}{ Business Performance (Y) } & \\
\hline Y1.1 & 0,000 & \multirow{3}{*}{0,889} & Valid dan Reliable \\
\hline Y1.2 & 0,000 & & Valid dan Reliable \\
\hline Y1.3 & 0,000 & & Valid dan Reliable \\
\hline
\end{tabular}

source: Internal source 2020

Based on Table 4.6, it can be seen that the significance value of each statement on each variable shows a significance value of 0.000 , which means that the sig value $<0.05$, so it can be concluded that each statement on each variable is declared valid. And it can be seen that Cronbach Alpha on the variable Customer relationship 0.688, Information quality 0.933, Information Technology 0.912, and Business Performance 0.889. An instrument indicator is declared reliable if it has a Cronbach Alpha value $>0.6$ so it can be concluded that each variable is reliable.

\section{Assumption Test and Multiple Linear Regression Analysis}

Tabel 4.7 Multiple Linear Regression Test

\begin{tabular}{|c|c|c|c|c|c|c|c|c|}
\hline \multicolumn{9}{|c|}{ Coefficientsa } \\
\hline \multirow{2}{*}{\multicolumn{2}{|c|}{ Model }} & \multicolumn{2}{|c|}{$\begin{array}{c}\text { Unstandardized } \\
\text { Coefficients }\end{array}$} & \multirow{2}{*}{$\begin{array}{c}\begin{array}{c}\text { Standardized } \\
\text { Coefficients }\end{array} \\
\text { Beta }\end{array}$} & \multirow[t]{2}{*}{$\mathrm{t}$} & \multirow[t]{2}{*}{ Sig. } & \multicolumn{2}{|c|}{$\begin{array}{l}\text { Collinearity } \\
\text { Statistics }\end{array}$} \\
\hline & & B & Std. Error & & & & Tolerance & VIF \\
\hline \multirow{4}{*}{1} & (Constant) & ,425 & ,580 & & 733 & 470 & & \\
\hline & Rata2_X1 & , 160 & ,077 & 214 & 2,077 & ,048 & ,989 & 1,012 \\
\hline & Rata2_X2 & ,557 & ,128 & ,513 & 4,335 & , 000 & ,747 & 1,338 \\
\hline & \begin{tabular}{|l|} 
Rata2_X3 \\
\end{tabular} & ,396 & , 100 & ,468 & 3,961 & ,001 & ,750 & 1,333 \\
\hline
\end{tabular}

source: Internal source 2020

The analysis begins with the heteroscedasticity test which can be seen that the correlation between the variables of Customer relationship (0.214), Information quality (0.513), and Information Technology (0.468) with unstandardized residuals has a significance value (sig 2-tailed) $>0.05$ so it can be concluded that heteroscedasticity did not occur. Furthermore, the multicollinearity test shows that the VIF value of each variable, namely Customer relationship (1.012), Information quality (1.338), and Information Technology (1.333) with unstandardized residuals has a VIF value for each variable less than 10 (VIF <10). The tolerance values for each variable are Customer relationship (0.989), Information quality (0.747), and Information Technology (0.750). Furthermore, multiple linear regression analysis is as follows:

$$
Y=0.425+0,160 X_{1}+0,557 X_{2}+0,396 X_{3}+0,05+e
$$

Based on the regression equation above, it can be seen that if the constant value is 0.425 , which means that if $\mathrm{X} 1, \mathrm{X} 2, \mathrm{X} 3$ are zero then the $\mathrm{Y}$ value is 0.425 . This shows that without being influenced by $\mathrm{X} 1, \mathrm{X} 2$, and $\mathrm{X} 3$ the respondent already has $\mathrm{Y}$ in him with a value a constant of 0.425 . The regression coefficient value $X 1$ shows a positive value of 0.160 which means there is a positive relationship between $\mathrm{X} 1$ and $\mathrm{Y}$. So it can be concluded that when $\mathrm{X} 1$ increases, then the $\mathrm{Y}$ value will increase by $16 \%$ assuming the 
values of $X 2$ and $X 3$ are constant. The regression coefficient value of $X 2$ shows a positive value of 0.557 which means there is a positive relationship between $\mathrm{X} 2$ and $Y$. So it can be concluded that when $X 2$ increases, the $Y$ value will increase by $55.7 \%$ assuming the values of $\mathrm{X} 1$ and $\mathrm{X} 3$ are constant. The regression coefficient value of $\mathrm{X} 3$ shows a positive value of 0.396 which means there is a positive relationship between X3 and Y. So it can be concluded that when $\mathrm{X} 3$ increases, the $\mathrm{Y}$ value will increase by $39.6 \%$ assuming the values of $\mathrm{X} 1$ and $\mathrm{X} 2$ are constant.

\section{Model Feasibility Test (F Test)}

Based on Table 4.8 below, it can be seen that the significance value is $0.000<0.05$, which means that it can be said that the analysis model has the right model feasibility.

\begin{tabular}{|l|l|r|r|r|r|r|}
\multicolumn{7}{|c|}{ Tabel 4.8 Uji Kelayakan Model (Uji F) } \\
\hline \multicolumn{2}{|l|}{ Model } & Sum of Squares & df & Mean Square & F & Sig. \\
\hline \multirow{3}{*}{1} & Regression & 8,739 & 3 & 2,913 & 23,221 &, $000^{\mathrm{b}}$ \\
\cline { 2 - 8 } & Residual & 3,261 & 26 &, 125 & & \\
\cline { 2 - 8 } & Total & 12,000 & 29 & & & \\
\hline
\end{tabular}

a. Dependent Variable: Average_Y

b. Predictors: (Constant), Average_X3, Average_X1, Average_X2

source: Internal source 2020

\section{Hypothesis Test (t test)}

The independent variable is said to have an effect on the dependent variable if the significance value is $<0.05$. Based on Table 4.7 it can be seen that the significance value of Customer relationship is 0.048 , Information quality is 0.035 , and Information Technology is 0.004 , it can be concluded that all variables have an effect on Business Performance.

\section{Correlation and Determination Coefficient $\left(\mathbf{R}^{2}\right)$}

The correlation coefficient obtained from the correlation calculation is used to determine the closeness of the relationship between two variables.

Tabel 4.12 Correlation and Determination Coefficient $\left(\mathrm{R}^{2}\right)$

\begin{tabular}{|c|c|c|c|c|}
\hline Model & $\mathrm{R}$ & $\begin{array}{c}\mathrm{R} \\
\text { Square }\end{array}$ & Adjusted R Square & $\begin{array}{c}\text { Std. Error of the } \\
\text { Estimate }\end{array}$ \\
\hline 1 &, $853^{\mathrm{a}}$ &, 728 &, 697 &, 354 \\
\hline
\end{tabular}

a. Predictors: (Constant), Average_X3, Average_X1, Average_X2

b. Dependent Variable: Average _Y

Based on Table 4.9 , it can be seen that the correlation coefficient $(R)$ is 0.853 , which means that the correlation between Customer relationship, Information quality, and Information Technology variables on Business Performance is 0.853 . The $\mathrm{R}$ value of the independent variable on the dependent variable is considered to be stronger if the $R$ value approaches the number 1 . Based on the correlation coefficient interpretation guidelines, it can be concluded that the relationship between the independent variable and the dependent variable is moderate because it is 0.853 . The coefficient of determination (R2) is 0.728 which means that the influence of the variable Customer relationship, Information quality, and Information Technology on Business Performance is $72.8 \%$ while the other $27.2 \%$ are influenced by other variables not examined in this study.

\section{Discussion}


A company's customer relationship practices can affect success in managing the basic supply chain and its performance. Customer relationship focuses on knowing about the perspective of organizational members on customers to produce products or services for customer satisfaction which in turn improves buyer-supplier relationships. They can understand the needs of the end consumer better and this enables them to be responsive to rapid market changes and bring responsiveness to improved business performance in the organization. Table 4.7 shows that the relationship between customer relationships and business performance is positive, which means that all elements of the customer relationship support the achievement of business performance in a sustainable manner at PT Putra Tunggal Perkasa. It can be concluded more optimal the implementation of customer relationships, the business performance will increase, therefore based on the results of the analysis it can be concluded that $\mathrm{H} 1$ is accepted.

Information can be a source of competitive advantage if in controlled and give results in an integrated form and a coordinated supply chain. Several studies have stated that there is a relationship between information quality and business performance (Hasan, 2013; Khan et al., 2019). They provide evidence that the quality of information has a positive impact on sustainable business performance. Timely and relevant use of information by all supply chain partners can provide a competitive advantage. Table 4.7 shows that the relationship between information quality and business performance is positive, which means that all elements of information quality support the achievement of business performance in a sustainable manner at PT Putra Tunggal Perkasa. It can be concluded that the better information quality, the business performance will increase, therefore based on the results of the analysis it can be concluded that $\mathrm{H} 2$ is accepted.

Information Technology serves as a low-cost alternative to previous communication with the availability of accurate information. The purpose of Information Technology is to increase customer satisfaction. Customer satisfaction can be fulfilled through timely delivery with accuracy, product availability, responsiveness and flexibility from service providers. Table 4.7 shows that the relationship between Information Technology and business performance is positive, which means that all elements of Information Technology support the achievement of Business performance in a sustainable manner at PT Putra Tunggal Perkasa. It can be concluded that the better Information Technology, the business performance will increase, therefore based on the results of the analysis it can be concluded that $\mathrm{H} 3$ is accepted.

\section{Research Implications}

The implications of this study indicate that the company's focus on customer relationships can improve the business performance of PT Putra Tunggal Perkasa in a sustainable manner. This relationship can provide many benefits for both parties, one of which is the reduction of risks that may occur when the supply chain process is running. For example, when problems occur in material distribution due to material damage or delays, if the company and customers have a good relationship, there will be a certain limit of tolerance for the company's inability to meet consumer needs on time. A good relationship with customers is not enough to ensure the achievement of sustainable business performance. Information quality is needed which will ensure the quality of information the company receives from and to customers. This is important because even the slightest misinformation that occurs can cause the fleet to be unavailable and lead to 
the failure of a project or an increase in project financing to an expeditionary service provider because of this. Therefore, it is hoped that the company will be able to sort information and carry out optimal information management in the course of a project. This is also due to the quality of the information technology used. Information technology is a very vital medium in sharing information to and from customers by the company. The quality of the information technology used by the company contributes to the speed at which the company makes strategic decisions to achieve business performance. When a company does not have adequate information technology, it is certain that it will be left behind by other companies in the capacity of the accessibility of a supply chain. The digital supply chain that is currently developing is closely related to the existence of information technology.

\section{Conclusion}

Based on the results of research on customer relationship variables, information quality, information technology, it can be concluded that these variables have a partial impact on business performance. This conclusion supports the study (Nouri Bagher, 2018) which shows the results that aspects of customer relationship, information quality, information technology have an impact on business performance.

\section{Suggestions and Limitations}

In the midst of the current Covid-19 pandemic, companies are currently facing many disruptions. This is an obstacle for the company to develop better. Companies can focus on several aspects such as customer relationships, information quality, information technology, which optimizes these three aspects to improve business performance in a sustainable manner. In further research, a comparative study can be used for several different types of shipping companies in order to gain a broader understanding of the supply chain and constraints that may have an impact on the business performance of the shipping company.

\section{REFERENCE}

Banerjee, M., \& Mishra, M. (2017). Retail supply chain management practices in India: A business intelligence perspective. Journal of Retailing and Consumer Services, 34, 248-259. doi:10.1016/j.jretconser.2015.09.009

Dyer, W. G. W. A. L. (1991). BETTER STORIES. NOT BETTER CONSTRUCTS- TO GENERATE BETTER THEORY: A REJOINDER TO EISENHARDT. Academy of Management Review, 16.

George, D. K., \& Xia, C. H. (2011). Fleet-sizing and service availability for a vehicle rental system via closed queueing networks. European Journal of Operational Research, 211(1), 198207. doi:10.1016/j.ejor.2010.12.015

Gorane, S., \& Kant, R. (2017). Supply chain practices and organizational performance. The International Journal of Logistics Management, 28(1), 75-101. doi:10.1108/ijlm-06-20150090

Hasan, M. (2013). Sustainable Supply Chain Management Practices and Operational Performance. American Journal of Industrial and Business Management, 03(01), 42-48. https://doi.org/10.4236/ajibm.2013.31006

Herden, T. T. (2017). Similarity-matching in decision-making processes of Supply Chain Analytics: A systematic literature review. Supply Chain Forum. https://doi.org/10.1080/16258312.2017.1278670 
Johannessen, J.-A., \& Johannessen, J.-A. (2018). Knowledge Management and Organizational Learning. Knowledge Management as a Strategic Asset, 95-111. https://doi.org/10.1108/978-1-78769-659-420181005

Kadir. (2015). Statistika Terapan. Jakarta: PT Rajagrafindo Persada.

Khan, S. A., Chaabane, A., \& Dweiri, F. (2019). A knowledge-based system for overall supply chain performance evaluation: a multi-criteria decision making approach. Supply Chain Management. https://doi.org/10.1108/SCM-06-2017-0197

Kumar, A., \& Kushwaha, G. S. (2015). Supply Chain Management Practices and Operational Performance of Fair Price Shops in India : an Empirical Study. Logforum, 14(1), 85-99. https://doi.org/10.17270/J.LOG.2018.237

Kurniawan, A. W., \& Puspitaningtyas, Z. (2016). Metode Penelitian Kuantitatif. In Philosophy of Science (Vol. 4). https://doi.org/http://dx.doi.org/10.1007/978-1-4419-8580-4_5

Li, S., Cui, X., Huo, B., \& Zhao, X. (2019). Information sharing, coordination and supply chain performance. Industrial Management \& Data Systems, 119(5), 1046-1071. https://doi.org/10.1108/IMDS-10-2018-0453

Manders, J., Caniëls, M. C. J., \& Ghijsen, P. (2014). Supply chain flexibility: a systematic literature review and research directions for future research. Annual IPSERA Conference, At Pretoria, South Africa, (November). https://doi.org/10.13140/2.1.4132.8324

Nouri Bagher, A. (2018). The effect of supply chain capabilities on performance of food companies. Journal of Finance and Marketing, 02(04). https://doi.org/10.35841/financemarketing.2.4.1-9

Roehrich, G. (2004). Consumer innovativeness - Concepts and measurements. Journal of Business Research, 57(6), 671-677. https://doi.org/10.1016/S0148-2963(02)00311-9

Stevenson, M., \& Spring, M. (2009). Supply chain flexibility: An inter-firm empirical study. International Journal of Operations and Production Management, 29(9), 946-971. https://doi.org/10.1108/01443570910986238

Sutrisno, T. F. C. W., \& Ardyan, E. (2020). Achieving Organizational Performance in Food Companies: The Critical Role of Leadership and Continuous Improvement as Part of TQM Practice. QUALITY Access to Succes, 21, 133-138.

Teofilus, T., Singh, S. K., Sutrisno, T. F. C. W., \& Kurniawan, A. (2020). Analyzing Entrepreneurial Marketing on Innovative Performance. Mix Jurnal Ilmiah Manajemen, 10(1). doi:10.22441/mix.2020.v10i1.006

Tortorella, G. L., Giglio, R., Limon-romero, J., Tortorella, G. L., \& Limon-romero, J. (2018). Supply chain performance: how lean practices efficiently drive improvements performance. https://doi.org/10.1108/JMTM-09-2017-0194

USAID Deliver. (2011). The Logistics Handbook: A Practical Guide for the Supply Chain Management of Health Commodities. USAID | DELIVER PROJECT, Task Order 1, 174. Retrieved from http://deliver.jsi.com/dlvr_content/resources/allpubs/guidelines/LogiHand.pdf

Zhao, L., \& Jung, H. B. (2018). The winning personality: Impact of founders' personality traits and firms' network relationships on Chinese apparel new venture performance. International Journal of Entrepreneurial Behaviour and Research, 24(2), 553-573. https://doi.org/10.1108/IJEBR-09-2016-0281 